\title{
An Opportunity for Values Education in Higher Education: Social Responsibility and Healthy Living Course
}

\author{
Gokhan Izgar \\ Department of Curriculum and Instruction, Necmettin Erbakan University, Turkey
}

\begin{tabular}{l}
\hline \hline Article Info \\
\hline Article history: \\
Received Jul 31, 2018 \\
Revised Aug 20, 2018 \\
Accepted Oct 16, 2018 \\
\hline
\end{tabular}

Keyword:

Action research

Social responsibility

Values education

\begin{abstract}
The purpose of this study is to determine the contribution of the "social responsibility and healthy living" course, which was put into effect at a state university for the first time in Turkey, within the scope of elective courses on students' acquisition of values. The data in this study, in which action research, one of the qualitative research designs, was conducted, were obtained using the semi-structured interview form prepared by the researcher. The data obtained were analyzed using the descriptive analysis and content analysis techniques, which are qualitative data analysis methods. 39 students participated in the study on a voluntary basis. As a result of the analysis of the data, it was concluded that the action plan developed within the scope of the social responsibility and healthy living course was effective in the acquisition of values of taking responsibility, charitableness, being useful, ethics, empathy, importance of the institution of family, cooperationsolidarity, patience, gratitude (thankfulness), freedom of thought and respect for differences. Likewise, some of the students stated that this course contributed to their views and behaviors concerning healthy living. However, a considerable number of students were of the opinion that either the course did not make a contribution or made a partial contribution. In addition, the students pointed out that the way the course was taught was fruitful and practice-based, that it was fun and informative and that the projects and readings contributed to learning. Yet, there were also negative student views about the course content and the method of teaching employed. Moreover, it was important that a theme emerged indicating that class hours were not sufficient.
\end{abstract}

Copyright (C) 2018 Institute of Advanced Engineering and Science. All rights reserved.

\section{Corresponding Author:}

Gokhan Izgar,

Department of Curriculum and Instruction,

Necmettin Erbakan University,

Toros Mahallesi, Üniversite Caddesi, No: 442310 Ereğli, Konya, Turkey.

Email: gizgar@konya.edu.tr

\section{INTRODUCTION}

Values education, which is one of the important issues of education at the point where mankind has reached in the light of the latest developments in information and technology, is not a new concept in fact and it was dealt with under such titles as character education, morality education and ethics in the past [1]. Studies conducted on values education began to be published after the mid-1970s and figures such as Rokeach (1973), Kirschenbaum (1977), Raths, Harmin and Simon (1978) came into prominence in these studies concerning values education. In the $1990 \mathrm{~s}$, on the other hand, importance attached to social and moral values decreased and values related to individual adaptation took center stage [2]. The pleasure-based lifestyle as well as worrisome cases such as violence, peer victimization, addiction and sexual degeneration into which young generations fell with the rise of modernity having remained distant from the effect of values that rendered life meaningful led values in education to be handled anew and with a new perspective 
in many countries [3]. However, the most important tool that will provide social cohesion and unity in social life is common values. The development of individuals with those common values is undoubtedly a matter of education.Therefore, values education emerges as an important area of research today that needs to be dwelt on seriously.

When the relevant literature is examined, it is seen that there are numerous studies conducted on values education [4-9]. Values education have been handled under three headings in the studies implemented with the regard to the issue. These involve the place of values education in teaching programs, methods and techniques that could be used in the teaching of values education and assessment of values education on the basis of teacher and student views [10]. The studies that were investigated within the scope of this study emphasized that especially preservice teachers and practicing teachers had to be informed of contemporary methods and techniques which they could use in values education.

Values are phenomena that can be taught and learned. People are not born with prior knowledge of values. The fact that values take different forms in different societies and are evaluated differently indicates that they are learned later in life. People learn how to behave in certain situations from adult individuals or their peers in the community in which they live. Hence, values are, above all, a subject of education. This education is not composed merely of courses taught at schools. In a way, the whole society is a school and each individual can be considered a teacher and a student of this school [11]. For this reason, it can be mentioned that the values education applied in the school can continue in social life outside the school.

If one makes an attempt at formulating the philosophy of education on which new educational practices are based today, it is seen that concepts such as self-expression and self-improvement, learning through experiences, seizing opportunities of the time and getting to know the changing world come to the forefront [12]. In this scope, learners' obtainment of the knowledge and skills they need to acquire through educational practices they will undergo within the society will enable individuals both to learn actively and contribute to social life. In this way, it will be possible to gain an awareness of social responsibility to learning individuals.

As a matter of fact, community service practices are being performed on a voluntary basis in Turkey at institutions of basic education so that students can be raised as individuals that are respectful to themselves, to their families and to the society, are sensitive to environment and social problems, and are problem-solvers with skills for cooperation with public and private institutions and non-governmental organizations [13]. The purpose of these activities is to fulfill the function of "socializing the individual", which is one of the goals of education [14]. Consequently, the most important task in socialization of the individual lies with the teachers. Therefore, it is of great significance that when they are students, teachers should undergo experiences in which they will be able to get to know the society, commune with the society, serve as an example to it and exhibit leadership skills. In this scope, The Higher Education Board decided in 2006 that a new course titled "Community Service" be included in the syllabuses of education faculties. In this way, students would be enabled to prepare projects aimed at determining contemporary problems of the society and finding solutions to them, in addition to scientific studies being conducted at education faculties and educational activities [15].

There are many studies in the relevant literature concerning the course Community Service [16-22]. These studies indicate that Community Service course contributes to students' academic and social learning processes and their personal and social developments [21]. It has also been concluded that students (people) should be involved in community services where they can do different tasks and that a significant increase has been observed in their leadership beliefs as a result [17]. Likewise, studies conducted within the scope of the community service course have arrived at the conclusion that the course is generally quite useful for students and that it has contributed to their communing with the society. In addition, it has been observed that students have become aware of social values such as being helpful, being a good person, being tolerant, being respectful, being responsible, sincere and fair and being sensitive to social problems. However, it has also been found that there are some problems regarding community service practices, and suggestions have been made with respect to these problems [23-30].

Today, institutions of education are far from being institutions that only transfer knowledge. Universities, which come into prominence especially due to their efforts aimed at gaining their students vocations, need to teach their students what kind of contributions they could make or have to make to the society in which they live in accordance with the knowledge they have acquired, in addition to providing them with basic information about their respective professions [31].

Based on this, it was decided that a "Social responsibility and healthy living" course be included in the syllabuses of all faculties at Konya Necmettin Erbakan University in Turkey beginning with the 20152016 academic year within the scope of compulsory and elective courses [32].

IJERE Vol. 7, No. 4, December 2018 : $331-340$ 
Within this scope, the primary purpose of this study is to determine the contribution of the action plan on students' acquisition of values developed by the researcher in the teaching of the course titled social responsibility and healthy living. The study also has two sub-goals in accordance with the primary goal stated above. The first sub-goal involves presentation of a model application concerning the implementation of the course "social responsibility and healthy living" whereas the second sub-goal involves making an assessment of students' views regarding the process.

\section{RESEARCH METHOD}

This study is an action research, which is one of the qualitative research designs. Action research is a application-oriented research model [38]. Action research is a process carried out by a practitioner or a researcher who is involved in the practice. It is a research approach that reveals problems related to the implementation process or systematically collecting and analyzing data to understand and provide solutions to a problem that has already emerged [33]. Although the said course was put into effect at all faculties of Konya Necmettin Erbakan University in the 2015-2016 academic years, no application or study has been encountered in the relevant literature on the topic. Hence, this study was designed to improve the course practice as there are no course books, materials and practices regarding the course in question. The action plan of the study was prepared and applied by the researcher himself who conducted the course "social responsibility and healthy living".

Pre-interviews were held with the students before the action plan was prepared in order to determine the research problem and the students' level of readiness. Practitioners' studying the process of application so that problems arising during the process of application could be understood and solved is one of the most fundamental features of action researches [33]. During the action research, the steps of identification of the problem, data collection, data analysis, development of an action plan, application of the action plan, analysis of the application and assessment were implemented in order. The timeline belonging to the said action plan is given in the appendix.

Table 1. Action Plan Timeline

\begin{tabular}{|c|c|c|}
\hline Process & Activities & Time period \\
\hline \multirow{4}{*}{$\begin{array}{l}\text { Before } \\
\text { Application }\end{array}$} & Literature review and preparation of a draft action plan & $15.01 .20018-15.02 .20018$ \\
\hline & Semi-structured interviews (Pre-interviews) & $19.02 .2018-20.02 .2018$ \\
\hline & $\begin{array}{l}\text { Identification of problems emerging as a result of an } \\
\text { analysis of literature review and pre-interview forms }\end{array}$ & $21.02 .2018-22.02 .2018$ \\
\hline & Preparation of the action plan & $23.02 .2018-25.02 .2018$ \\
\hline Application & Application of the action plan & $26.02 .2018-31.05 .2018$ \\
\hline After & Semi-structured interviews (post-interviews) & 01.06 .2018 \\
\hline Application & Analysis and assessment of the application & -17.06 .2018 \\
\hline
\end{tabular}

\subsection{Research group}

The study was conducted in the spring semester of the 2017-2018 academic year. The working group of the study consisted of 1st year students at Konya Necmettin Erbakan University Ereğli Education Faculty Department of Guidance and Counselling. Initially, 42 students participated in the study. However, the numbers of particapants have decreased for various reasons. 39 students participated in the semistructured interviews within the scope of the study on a voluntary basis.

\subsection{Research procedures}

According to the senate decision 7 of Konya Necmettin Erbakan University Rectory in 2015, the course content of "social responsibility and healthy living" covers 12 subjects and 2 model applications. Therefore, the course was so designed as to include teaching of a subject (1 class hour) every week and review of model applications in the last two weeks [32]. Explanatory information about the action plan prepared in regard to the "social responsibility and healthy living" course in the study is presented below. Application 1, application 2 and evaluation steps were developed by the researcher.

Application-1 (Classroom Activities):

1- Each student will read an article s/he has chosen from scholarly journals about the subject within the scope of the course and analyze it.

2- Taking into account the classroom size, 3 students will present analyses of their articles for each subject, i.e. each week. 
3- Article analysis will consist of 2 pages at the most and each student's presentation will take 10 minutes. At the end of article analysis, important aspects of the subject will be summarized in the classroom using the question-answer technique.

4-A printout of the article analysis will be submitted to the course instructor. Information about the article analysis is given in Table 2 .

Table 2. Scope of Article Analysis

\begin{tabular}{cl} 
& \multicolumn{1}{c}{ Article Analysis } \\
\hline $1-$ & What is the identity of the article? \\
$2-$ & What field is the subject of the article related to? \\
$3-$ & What is the primary purpose of the article? \\
4- & What are the conclusions and suggestions arising from the article? \\
$5-$ & Explain what you have learned from the article about the research subject? \\
\hline
\end{tabular}

Applicatıon-2 (Extracurricular Activities):

1-A project topic will be determined according to the course content within the scope of cooperative learning and the extracurricular activity and group work will be employed outside of classroom hours. Project topics and explanatory information are given in Table 3.

2-A project form containing information like the name-purpose-time of the project will be approved by the course instructor and then the project work will be initiated. Information about the project form is shown in Table 4.

3 -The projects conducted will be presented in the classroom in the 13th and 14th weeks and their results will be discussed.

Table 3. Project Topics and Explanatory Information

\begin{tabular}{|c|c|c|}
\hline Project Topic & $\begin{array}{c}\text { Number of Students } \\
\text { Participating in the Study }\end{array}$ & $\begin{array}{c}\text { Date of Project } \\
\text { Presentation }\end{array}$ \\
\hline Social Responsibility and University & $5(1$ group $)$ & 22.05 .2018 \\
\hline Non-Governmental Organizations & 5 (1 group) & 22.05 .2018 \\
\hline Ethical Values & 5 (1 group) & 22.05 .2018 \\
\hline 1-The Family Institution & & \\
\hline $\begin{array}{l}\text { 2-Intra-family Communication } \\
\text { 3-Marriage }\end{array}$ & 5 (1 group) & 22.05.2018 \\
\hline $\begin{array}{l}\text { Gender Equality } \\
\text { 1-General Overview of Health }\end{array}$ & 5 (1 group) & 29.05.2018 \\
\hline $\begin{array}{l}\text { 2-Preservation of Healthy living } \\
\text { 3-Threats against Healthy living (Addictions) }\end{array}$ & 9 (2 groups) & 29.05.2018 \\
\hline Basic First Aid & 5 (1 group) & 29.05 .2018 \\
\hline
\end{tabular}

Table 4. Project Form

Name of the Project:
Project location:
Project Commencement Date:
Project Completion Date:
Project Implementers:
Target Audience:
Project Topic:
Project Goals:
Project Application Process:
Project Implementers' Self-Assessment:
Appendices (photographs, video records,
documents etc.):

The action plan for the course "Social Responsibility and Healthy living" indicating the purpose of the course (course objectives), its content, educational circumstances and assessment is shown in Table 5. 
Table 5: Action Plan for the Course Social Responsibility and Healthy Living

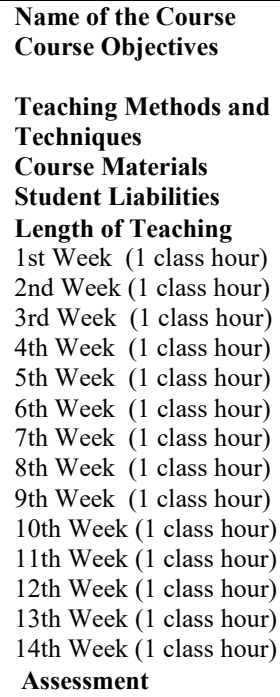

Social responsibility and healthy living

Fulfilling responsibilities expected of students in ensuring social unity and peace as individuals living in social life and gaining knowledge and skills concerning healthy living

Cooperative learning, extra-curricular activities, discussion method, question-answer method, Project technique

Reading (Article-book) - Lecture notes (Article analyses)

Application 1 - Application 2

Course Content

People and responsibility

Social responsibility and university

Non-governmental organizations

Ethical values

Family and its importance

Marriage and a healthy beginning to marriage

Gender equality

Intra-family communication

General overview of health

Preservation of healthy living

Threats against healthy living (Addictions)

Basic first aid-First aid in emergencies

Model applications in social responsibility

Model applications in social responsibility

Written examination (40\%) : Reading - Lecture notes

Rubric (40\%) : Project report

Rubric $(20 \%)$ : Article analysis

\subsection{Data collection tools}

Semi-structured interviews were held with the students in the study in order to both obtain data that were expected to shed light on improving the action plan and to make an assessment of the action plan on the basis of student views. While interview forms were being prepared, attention was paid so that the questions could be easily understood, there would not be overlapping questions and there would not be questions already including answers within them. To ensure validity of the forms prepared, views of two field experts were obtained. Pilot interviews were held with a few students concerning the interview form corrected in accordance with the suggestions made by the experts and its final form was given to the interview form after correction of the questions or statements that were not understood or did not serve the purpose.

\subsection{Analysis of the data}

The qualitative data obtained from the pre-interviews in this study were analyzed using the "Descriptive Analysis" technique. The themes used in the analysis of the data were formed in the light of semi-structured interview form prepared by the researcher. The data obtained from the final interviews, on the other hand, were analyzed using the content analysis technique. The basic procedure in content analysis is to bring together similar data around certain concepts and themes and arrange and interpret them in such a way that readers will be able to understand them [33]. During data analysis, words, sentences and paragraphs were encoded through conceptualization so as to determine the idea intended to be communicated within the scope of the study. Sample view and code list used in the content analysis is given in Table 6.

Table 6. Sample Content Analysis and Code List

\begin{tabular}{lr}
\hline \multicolumn{1}{c}{ View } & Code \\
\hline$\ldots$ the first aid project has helped me learn how to help people in time of an & Charitableness \\
emergency and how precious human life is. & Right to live \\
... for example, I have learned in special education that I should be respectful & Empathy
\end{tabular}

to special needs people and act so that they will not feel bad within society... (S-4)

...we learned to work in groups and distribute tasks among ourselves. (S-13)

...or when clothes were gathered, I saw that extra ones were not useful to me

Cooperation-solidarity whereas they made other people happy. I learned that some items that were minor for us were perhaps dreams objects for others. (S-4)

...if your ideas are well-intended, this is reflected in your behaviors and this in turn is based on your mental health. I have learned in the course what healthy living highlights and indeed everything contributes to this. (S-10)

I think although the class lasted just an hour, we used it effectively. ...this semester, we read an important book and I implemented a project, which was useful for us...(S-33)

Caring about mental health

Course hour is inadequate Course is taught efficiently Readings have contributed to learning 


\begin{tabular}{lr}
\hline \multicolumn{1}{c}{ View } & Code \\
\hline $\begin{array}{l}\text { I would not teach this course at all because these subjects are things that we } \\
\text { have all along learned from our families and environment. ...this class hour }\end{array}$ & $\begin{array}{r}\text { learning } \\
\text { should have been added to a more useful course. (S-29) }\end{array}$ \\
$\begin{array}{l}\text {..Classes are efficient for those making their presentations, but contribution } \\
\text { and participation of students as listeners is limited. }\end{array}$ & beneficial \\
two hours for it to be more useful ... (S-20) & $\begin{array}{r}\text { Discussions are insufficient } \\
\text { Course hour is inadequate }\end{array}$ \\
\hline
\end{tabular}

In order to ensure reliability of the encoding performed for the themes within the scope of the study, the data obtained from the interview forms were encoded by the researcher again at different times and assessed. Situations where the same coding was done were recorded using the phrase "agreement" whereas situations where different coding was done were recorded using the phrase "disagreement". As a result of the calculations made after determination of agreements where the same coding was done and disagreements where different coding was done at the end of data analysis, mean reliability score among the coding was found to be $78 \%$. When reliability score is above $70 \%$, it is enough for a study to be regarded as reliable [34].

In qualitative studies, the concept of "transferability" is used instead of external validity (generalization). The responsibility of a qualitative researcher is to reveal the transferability degree of the results he or she obtained to similar environments. To this end, direct citations are often included [33]. Therefore, direct citations were made in the study to ensure transferability and the citations were presented in inverted commas and italics and without making any changes to them. Abbreviated information indicating from whom the citation was made was included at the end of each direct citation. For example, the abbreviation "S-3" means it is the "3rd student interviewed".

\section{RESULTS AND ANALYSIS}

3.1. Findings Revealing Students' Readiness Levels Concerning the Course Content Before Application

The students' readiness levels concerning the course content before the application were revealed through the interviews held within the scope of the study. The students' views are given in Table 7.

Table 7.Students' Readiness Levels Concerning the Course Content before the Application

\begin{tabular}{|c|c|c|}
\hline Interviews Questions & 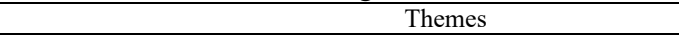 & $\mathrm{f}$ \\
\hline \multirow{16}{*}{$\begin{array}{l}\text { In general, which values do you } \\
\text { attach importance to in social } \\
\text { life? }\end{array}$} & Respect & 21 \\
\hline & Justice & 4 \\
\hline & Equality & 3 \\
\hline & Moral values & 10 \\
\hline & Religious values & 4 \\
\hline & National values & 5 \\
\hline & Love & 15 \\
\hline & Charitableness & 7 \\
\hline & Environment & 3 \\
\hline & Responsibility & 3 \\
\hline & Tolerance & 5 \\
\hline & Trust & 4 \\
\hline & Human rights & 5 \\
\hline & Compassion & 2 \\
\hline & Freedom & 2 \\
\hline & Friendship & 2 \\
\hline \multirow{11}{*}{$\begin{array}{l}\text { Did you participate in any } \\
\text { social responsibility activity? If } \\
\text { so, what kind of activities did } \\
\text { you take part in? }\end{array}$} & Yes, I did. & 29 \\
\hline & No, I didn't. & 10 \\
\hline & Helping handicapped individuals & 4 \\
\hline & Collecting second-hand books & 2 \\
\hline & Collecting garbage and waste material & 7 \\
\hline & Helping the poor & 2 \\
\hline & Tree-planting campaigns & 5 \\
\hline & Helping and visiting village schools & 5 \\
\hline & Visits to old people's homes, women's shelters and orphanages & 7 \\
\hline & Offering tuitions free of charge & 1 \\
\hline & Blood donation & 2 \\
\hline \multirow{4}{*}{$\begin{array}{l}\text { Do you think you lead a } \\
\text { healthy living? Explain. }\end{array}$} & Yes, I do. & 13 \\
\hline & No, I don't & 14 \\
\hline & I think so partially & 12 \\
\hline & Harmful foodstuffs (cola, crisps, fast-food etc.) are consumed & 8 \\
\hline
\end{tabular}

IJERE Vol. 7, No. 4, December 2018: $331-340$ 
Harmful foodstuffs (cola, crisps, fast-food etc.) are not consumed

I don't have a healthy diet

I have a healthy diet

Harmful substances such as alcohol, cigarettes etc. are not used

Harmful substances such as alcohol, cigarettes etc. are used

Exercise is done

There is not a regular sleep pattern

As a result of the interviews on the values of the students, a total of 95 opinions have emerged under 16 themes. When Table 7 is examined, it is seen that a large majority of the students attach importance to especially respect, love and moral values in social life $(\mathrm{f}=46)$ but they attach less importance to some values such as charity, preservation of environment, tolerance, friendship, responsibility and human rights, which ensure social integrity and peace. Likewise, some of the students $(\mathrm{f}=10)$ stated that they had not participated in any social responsibility activity before. Moreover, a large majority of the students $(\mathrm{f}=26)$ stated that they led a partially healthy living or did not lead a healthy living at all.

\subsection{Findings Revealing Students' Views Concerning the Course after the Application}

The students' views concerning the course after the application were revealed through the interviews held within the scope of the study. The students' views are given in Table 8.

Table 8.The Students' Views Concerning the Course after the Application

\begin{tabular}{|c|c|c|}
\hline Interview Questions & Themes & $\mathrm{f}$ \\
\hline \multirow{15}{*}{$\begin{array}{l}\text { Within the scope of this course, you have } \\
\text { implemented projects, read articles and } \\
\text { analyzed them. Did these practices make } \\
\text { any contribution to your system of values? } \\
\text { Explain. }\end{array}$} & Ethics & 15 \\
\hline & Cooperation-Solidarity & 7 \\
\hline & Responsibility & 19 \\
\hline & Empathy & 6 \\
\hline & Charitableness & 8 \\
\hline & Right to live & 3 \\
\hline & Importance of the institution of family & 2 \\
\hline & Gender equality & 6 \\
\hline & Justice & 1 \\
\hline & Trust & 4 \\
\hline & Being useful & 14 \\
\hline & Patience & 2 \\
\hline & Freedom of thought- Respect for differences & 4 \\
\hline & Gratitude & 1 \\
\hline & Respect & 1 \\
\hline \multirow{9}{*}{$\begin{array}{l}\text { Did this course make any contribution to } \\
\text { your views and behaviors concerning } \\
\text { healthy living? Explain. }\end{array}$} & Yes, it did. & 15 \\
\hline & Yes, it did partially & 5 \\
\hline & No, it didn't & 9 \\
\hline & Healthy diet & 5 \\
\hline & Hygiene & 3 \\
\hline & Personal care & 2 \\
\hline & First aid & 5 \\
\hline & Mental health & 10 \\
\hline & Exercise & 3 \\
\hline \multirow{14}{*}{$\begin{array}{l}\text { What are your suggestions, criticisms and } \\
\text { ideas about the way the course was taught? } \\
\text { Explain. }\end{array}$} & Class hour is adequate & 4 \\
\hline & Class hour is inadequate & 22 \\
\hline & Classes are taught efficiently and are practice-based & 18 \\
\hline & Classes are taught in a fun and instructive way & 4 \\
\hline & Course content is beneficial & 21 \\
\hline & The projects have contributed to learning & 12 \\
\hline & Readings have contributed to learning & 6 \\
\hline & The course should have been practice-based & 3 \\
\hline & Reading of articles was not beneficial & 2 \\
\hline & There should have been more discussion & 4 \\
\hline & Course content is not beneficial & 1 \\
\hline & Classes are taught in a fun way & 1 \\
\hline & There are no classroom resources for the course & 2 \\
\hline & There should have been more informative videos and slides & 2 \\
\hline
\end{tabular}

As a result of the interviews about the contribution of the performed applications to the values system, a total of 93 opinions have appeared under 15 themes. When Table 8 is examined, it is seen that a large majority of the students $(\mathrm{f}=56)$ stated their views about the importance of values such as responsibility,

An Opportunity for Values Education in Higher Education: Social Responsibility and ... (Gokhan Izgar) 
charitableness, being useful and ethics, which ensure continuity and integrity of social life. The increase in the value of taking responsibility ( $\mathrm{f}=19)$, in particular, is worthy of attention. Likewise, it is seen that students mention new values after the application. These are ethics $(f=15)$, empathy $(f=6)$, importance of the institution of family $(\mathrm{f}=2)$, being useful $(\mathrm{f}=14)$, cooperation-solidarity $(\mathrm{f}=7)$, patience and gratitude $(\mathrm{f}=3)$, freedom of thought and respect for differences $(\mathrm{f}=4)$. Views of some students concerning the subject are as follows:

“We went to a senior center. Seeing that senior center is a necessity really hurt me ...” (S-21)

"...I will always link them in my life as a student, as a teacher and in my family, and try to implement them. I had some apprehensions about responsibility initially but now I can take all kinds of responsibility." (S-35)

Likewise, some of the students $(\mathrm{f}=15)$ stated that this course had made contributions to their views and behaviors regarding healthy living. However, a considerable number of students $(\mathrm{f}=14)$ stated that there was not any kind of contribution or there was partial contribution. In addition, there were students $(\mathrm{f}=10)$ emphasizing that not only physical health but also mental health is important with respect to healthy living. Some student views concerning the subject are as follows:

"...I obtained clues as to a healthy living for a healthy mental state." (S-26)

"To tell the truth, I haven't learned much that is new regarding healthy living. ...only, it was good that I updated basic first aid information." (S-3)

When students' views concerning suggestions, criticisms and ideas about the way the classes were taught are examined, it is observed that the themes that the way the classes were taught were efficient and practice-based, fun and informative (instructive); projects and readings contributed to learning and course content was beneficial $(\mathrm{f}=61)$ came into prominence. However, there are also unfavorable views regarding the way the classes were taught as well as course content $(\mathrm{f}=15)$. In addition, it is challenging that there are student views claiming that class hours were inadequate $(\mathrm{f}=22)$. A few of the student views concerning the subject are as follows:

"...Readings have helped me learn about the profession. I have obtained accurate information about teacher behaviors and ethical values, about which I had been wrongly informed for years ..." $(S-14)$

"...We both worked in groups and made extremely useful observations." (S-25)

"...Time was limited; therefore, we had to present our projects in a hasty manner. There was no time left for fruitful discussion." (S-36)

\section{DISCUSSION}

When the research findings are examined, it is seen that project work, activities, readings and discussions performed within the scope of the study influenced students' acquisition of values. In a study by [35], which is in support of the finding of this study, it was concluded that some values not offered in the syllabus were able to be gained the students through various activities and materials. Research findings indicate that the students frequently mentioned values such as taking responsibility, being useful and cooperation-solidarity. This result is consistent with the findings of a study conducted by [8]. It was concluded in the study carried out by [8] the "Moral Development Program" implemented in the study had led to significant increases in the participants' scores in taking responsibility.

The findings of the present study are also supported by studies conducted by [1], [5] and [9]. It was observed in those studies that significant increases had occurred in the experimental group students' scores in the freedom, responsibility, being peaceful, patience, honesty and tolerance dimensions. Likewise, in the research findings of studies by [4] and [7], students in the experimental groups used statements reflecting characteristics of the values and managed to analyze the values multi-dimensionally.

In a study in which [36]'s investigated views of teachers and school principals regarding the subject, pointed out that although there were some favorable changes in the Turkish Education System, the educational system failed to gain students adequate democratic attitudes and behaviors. A similar study was conducted by [37]. According their research findings, it was necessary that for students to gain the target values, values education be included in planned activities of syllabuses. The findings of these two studies indicate that values which were tried to be given to students through covert programs at educational institutions could not be transferred to the students at the desired level and that behaviors and sense of responsibility expected of students could not be observed at sufficient levels. Moreover, it was suggested that planned activities were needed in values education and efforts should be made in this regard. According to

IJERE Vol. 7, No. 4, December 2018: $331-340$ 
these results, the importance and effect pf the action plan prepared within the scope of the study may provide us with ideas about how to meet the shortage in regard to values education within the education system.

Likewise, when studies conducted within the scope of the community service course are examined, it is seen that they have reached results supporting the findings of this study. It was observed in studies conducted within the scope of the course community service that students became aware of social values such as being a charitable person, a good person and a good citizen, being a sharing and tolerant person, being respectful, being responsible, sincere and fair, and being sensitive to issues like communication, solidarity and social problems. Furthermore, it was concluded that significant increases had occurred in students' academic learning, personal and interpersonal development, their belief in their ability to do something different and especially in their leadership beliefs [17], [21], [25], [26].

\section{CONCLUSION AND SUGGESTIONS}

When the research findings are examined, it is seen that some of the students $(\mathrm{f}=14)$ were of the opinion that this course had not made any contribution to their views and behaviors concerning healthy living or it had made only partial contribution. Moreover, it was challenging to meet some student views stating that course content was not beneficial; the course was not practice-based; the classes were not taught in an amusing way; readings were not useful; there were not sufficient materials for the course, and there should have been more discussions $(\mathrm{f}=15)$. At this point, unfavorable student views could be linked to inadequate class hour. In other words, the course social responsibility and healthy living covers a total of 14 hours throughout the semester, which involves 12 topics and examination of model applications. Therefore, only 2 class hours were allocated to students' presenting their projects and discuss project results [32]. While the researcher was preparing the action plan, he planned the project applications within the scope of extracurricular activities, taking into consideration the time constraint and excess of topics. In addition, since there were no course books, materials etc. for the course, he planned article reading and analysis, and topic discussions as classroom activities. Also, 4 class hours were devoted in the course content to the subject of healthy living [32]. It is thought that this allocated time will be insufficient to gain the knowledge and skills concerning healthy living. When student views are examined, findings supporting this situation are observed. This so much so that some students stated that the class hour $(\mathrm{f}=22)$ and discussions $(\mathrm{f}=4)$ were inadequate. However, it should also be taken into consideration that there were student views stating that the classes were taught in an amusing, informative and efficient manner and that they were practice-based; the projects and readings had an effect on learning and acquisition of values $(\mathrm{f}=61)$ and contributed to knowledge and skills related to healthy living ( $\mathrm{f}=43$ ).

As a result of an analysis of the findings, it was seen that the class hour allocated for social responsibility and healthy living course was insufficient and that course content included too many topics. Based on this, it could be suggested that the class hour of the "social responsibility and healthy living" course be increased or course content be reduced.

Moreover, the themes stating that article reading and course content are not beneficial; the classes are not taught in an amusing way; there are no course materials, and there should have been more informative videos and slides ( $\mathrm{f}=8$ ) should be taken into consideration. This could be linked to absence of books or materials belonging to the said course. Therefore, it could be suggested that materials like books etc. should be prepared for the said course.

\section{REFERENCES}

[1] Izgar, G \& Eliüşük Bülbül, A. Değerler Eğitiminde Sabır. Sabır Eğitiminde Uygulanabilecek Örnek Etkinlikler. Konya: Eğitim Yayınevi. 2017.

[2] Demircioğlu, İ. \& Tokdemir, M. "Değerlerin Oluşturulma Sürecinde Tarih Eğitimi: Amaç, İşlev ve İçerik". Değerler Ĕgitimi Dergisi, 6(15), 69-88; 2008.

[3] Kaymakcan, R. \& Meydan, H. (2011). Din Kültürü ve Ahlâk Bilgisi Programları ve Öğretmenlerine Göre Değerler Eğitimi. Değerler Ĕ̈itimi Dergisi, 9(21), 27-51.

[4] Demirtaş, S. "Çocuk Yuvasında Kalan Korunmaya Muhtaç Çocukların Değer Eğitiminde Yaratıcı Dramanın Etkililiği”. (Yayımlanmamış Doktora Tezi). Hacettepe Üniversitesi Sosyal Bilimler Enstitüsü, Ankara; 2009.

[5] Dilmaç, B. Bir Grup Fen Lisesi Öğrencisine Verilen İnsani Değerler Eğitiminin İnsani Değerler Ölçeği İle Sınanması. (Yayımlanmamış Doktora Tezi). Selçuk Üniversitesi Sosyal Bilimler Enstitüsü, Konya; 2007.

[6] Eliüşük Bülbül, A. \& Izgar, G. "Effects of the Patience Training Program on Patience and Well-Being Levels of University Students". Journal of Education and Training Studies, 6(1), 159-168; 2018.

[7] İşcan, C. D. İlköğretim Düzeyinde Değerler Eğitimi Programının Etkililiği. (Yayımlanmamış Doktora Tezi). Hacettepe Üniversitesi Sosyal Bilimler Enstitüsü, Ankara; 2007.

[8] Krop, E. H. The Effects of a Cognitive-Moral Development Program on Inmates in a Correctional Educational Environment. (Unpublished doctoral thesis). Viginia University. USA; 2006. 
[9] Lamberta, G. C. A Values Education Intervention through Therapetic Recreation for Adolescants in a Psychiatric Setting. (Unpublished doctoral thesis). Valden University; 2004

[10] Elbir, B. \& Bağcı, C. "Değerler Eğitimi Üzerine Yapılmış Lisansüstü Düzeyindeki Çalışmaların Değerlendirilmesi”. Turkish Studies, 8(1), 1321-1333; 2013.

[11] Aydın, M.Z. Okulda Değerler Eğitimi. Ankara: Nobel Yayın ve Dağııı; 2012.

[12] Dewey, J. Tecrübe ve Eğitim. (F.Başaran, F.Varış, çev.) Kappa Delta Pi Yayınları; 1966.

[13] Millî Eğitim Bakanlığı. Millî Eğitim Bakanlığı Eğitim Kurumları Sosyal Etkinlikler Yönetmeliği. Resmî Gazete. Say1: 30090; 2017.

[14] Başaran, İ.E. Eğitim Psikolojisi (9. Baskı). Ankara; 1988.

[15] Yüksek Öğretim Kurulu. Eğitim Fakültelerinde Uygulanacak Yeni Programlar Hakkında Açıklama. Erişim tarihi: 25.04.2018; 2006. http://www.yok.gov.tr/documents/10279/49665/aciklama_programlar/aa7bd091-9328-4df7-aafa2b99edb6872f

[16] Allen, R.F. "School-based community service learning: Developing civic Commitment through action". The Social Studies, 88(5), 196; 1997.

[17] Giles, D.E. \& Eyler, J.S. "The impact of a college community service laboratory on students' personal, social and cognitive outcomes". Journal of Adolescence, 17, 327-339; 1994.

[18] Howard, J. Service-learning research: Foundational issues. In S. H. Billig \& A. S. Waterman (Eds.), Studying service-learning: Innovations in education research methodology (pp. 1-12). Mahwah, NJ: Lawrence Erlbaum; 2003.

[19] Quezada, R. L. \& Christopherson R. W. "Adventure-based service learning: University students' self-reflection accounts of service with children”. Journal of Experiential Education, 28 (1), 1-16; 2005.

[20] Owen, D. Service learning and political socialization. American Political Science Association, 33(3), 638; 2000.

[21] Simons, L. \& Cleary, B. "The influence of service learning on students' personal and social development". College Teaching 54 (4), 307-319; 2006.

[22] Wade, A \& Demb, A. "A conceptual model to explore faculty community engagement". Michigan Journal of Community Service Learning, 15(2), 5-16; 2009.

[23] Beldağ, A., Yaylacı, A.F., Gök, E. \& İpek, C. "Topluma Hizmet Uygulamaları Dersinin Üniversite-Toplum İşbirliği Açısından Değerlendirilmesi”. Ahi Evran Üniversitesi Kırşehir Eğitim Fakültesi Dergisi, 16(2), 161-178; 2015.

[24] Boran, M. \& Karakuş, F. "Topluma Hizmet Uygulamaları Dersine Yönelik Öğretmen Adayı Görüşlerinin İncelenmesi”. Erciyes Journal of Education, 1, 22-41; 2017.

[25] Bulut, M., Bulut,N. \& Bulut, A. Öğretmen Eğitiminde Değer Eğitimi Fırsatı Olarak Topluma Hizmet Uygulamaları Dersi. Mustafa Kemal Üniversitesi Sosyal Bilimler Enstitüsü Dergisi, 9(17), 347-357; 2012.

[26] Elma, C., Kesten, A., Kıroglu, K., Uzun, E.M., Dicle, A.N. \& Palavan, Ö. “Öğretmen Adaylarının Topluma Hizmet Uygulamaları Dersine İlişkin Algıları”. Kuram ve Uygulamada Ĕgitim Yönetimi, 16 (2), 231- 252; 2010.

[27] Ergül, H.F. \& Kurtulmuş, M. "Sosyal Sorumluluk Anlayışının Geliştirilmesinde Topluma Hizmet Uygulamaları Dersine İliş̧kin Öğretim Elemanlarının Görüşleri”. Elektronik Sosyal Bilimler Dergisi, 13(49), 221-232; 2014.

[28] Kocadere, S.A. \& Seferoğlu, S.S. “Topluma Hizmet Uygulamaları Dersinin İşlenişi: Uygulama Örnekleri ve Sürece İlişkin Öğrenci Görüşlerinin Değerlendirilmesi”. Pamukkale Üniversitesi Ĕ̆itim Fakültesi Dergisi, 34, 75-89; 2013.

[29] Sönmez, Ö.F. "Sosyal Bilgiler Öğretmen Adaylarının Topluma Hizmet Uygulamaları Dersine Yönelik Görüşlerinin Kazanım Boyutunda Değerlendirilmesi”. The Black Sea Journal of Social Sciences, 2, 53-72; 2010.

[30] Yılmaz, K. "Eğitim Fakültelerinin Sosyal Sorumluluğu Ve Topluma Hizmet Uygulamaları Dersi: Nitel Bir Araştırma”. Kuramsal Eğitimbilim, 4 (2), 86-108; 2011.

[31] Saran, M., Coşkun, G., İnal Zorel, F. \& Aksoy, Z. Üniversitelerde Sosyal Sorumluluk Bilincinin Geliştirilmesi: Ege Üniversitesi Topluma Hizmet Uygulamaları Dersi Üzerine Bir Araştırma. Journal of Yasar University, 22(6), 3732$3747 ; 2011$.

[32] Necmettin Erbakan Üniversitesi. Ortak Zorunlu Seçmeli Dersler. Say1:48178250.302/830; 2015.

[33] Yıldırım, A. \& Şimşek, H. Sosyal Bilimlerde Nitel Araştırma Yöntemleri (Beşinci baskı). Ankara: SeçkinYayıncılık; 2005.

[34] Miles, M. B., \& Huberman, A.M. Qualitative data analysis: An expanded sourcebook (2nd Edition). Calif: SAGE Publications; 1994.

[35] Çengelci, T. İlköğretim Beşinci Sinıf Sosyal Bilgiler Dersinde Değerler Ĕ̈itiminin Gerçekleştirilmesine İlişkin Bir Durum Çalışması. (Yayımlanmamış Doktora Tezi). Anadolu Üniversitesi Sosyal Bilimler Enstitüsü, Eskişehir; 2010.

[36] Yağan, S. Bağımsız Anaokullarında Görev Yapan Öğretmenlerin ve Okul Müdürlerinin Demokrasi ve Demokrasi Ĕ̆itimi İlişkin Görüşleri: Eskişehir İli Örneği. (Yayımlanmamış Yüksek Lisans Tezi). Anadolu Üniversitesi Eğitim Bilimleri Enstitüsü, Eskişehir; 2010.

[37] Deveci, H. \& Selanik Ay, T. İlköğretim Öğrencilerinin Günlüklerine Göre Günlük Yaşamda Değerler. Uluslararası Sosyal Araştırmalar Dergisi, 2(6), 167- 181; 2009.

[38] Creswell, J. W. Educational research: Planning, conducting, and evaluating quantitative and qualitative research (4th Edition). Boston: Pearson; 2012.

IJERE Vol. 7, No. 4, December 2018: $331-340$ 